vol. 12, no. 5

\title{
HISTORY OF THE CALUMET AND OF THE DANCE
}

\author{
BY \\ JACQUES LE SUEUR, S.J.
}

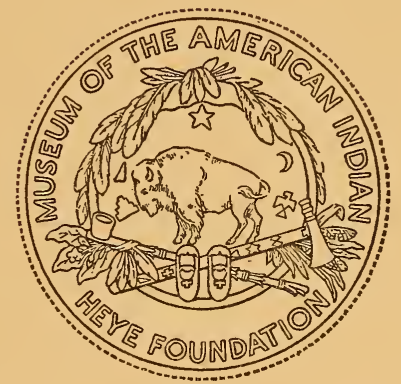

Vol. XII, No. 5

CONTRIBUTIONS FROM THE

MUSEUM OF THE AMERICAN INDIAN

HEYE FOUNDATION

NEW YORK • 1952 



H IS TOR Y OF THE CALUME T AND OF THE DANCE 


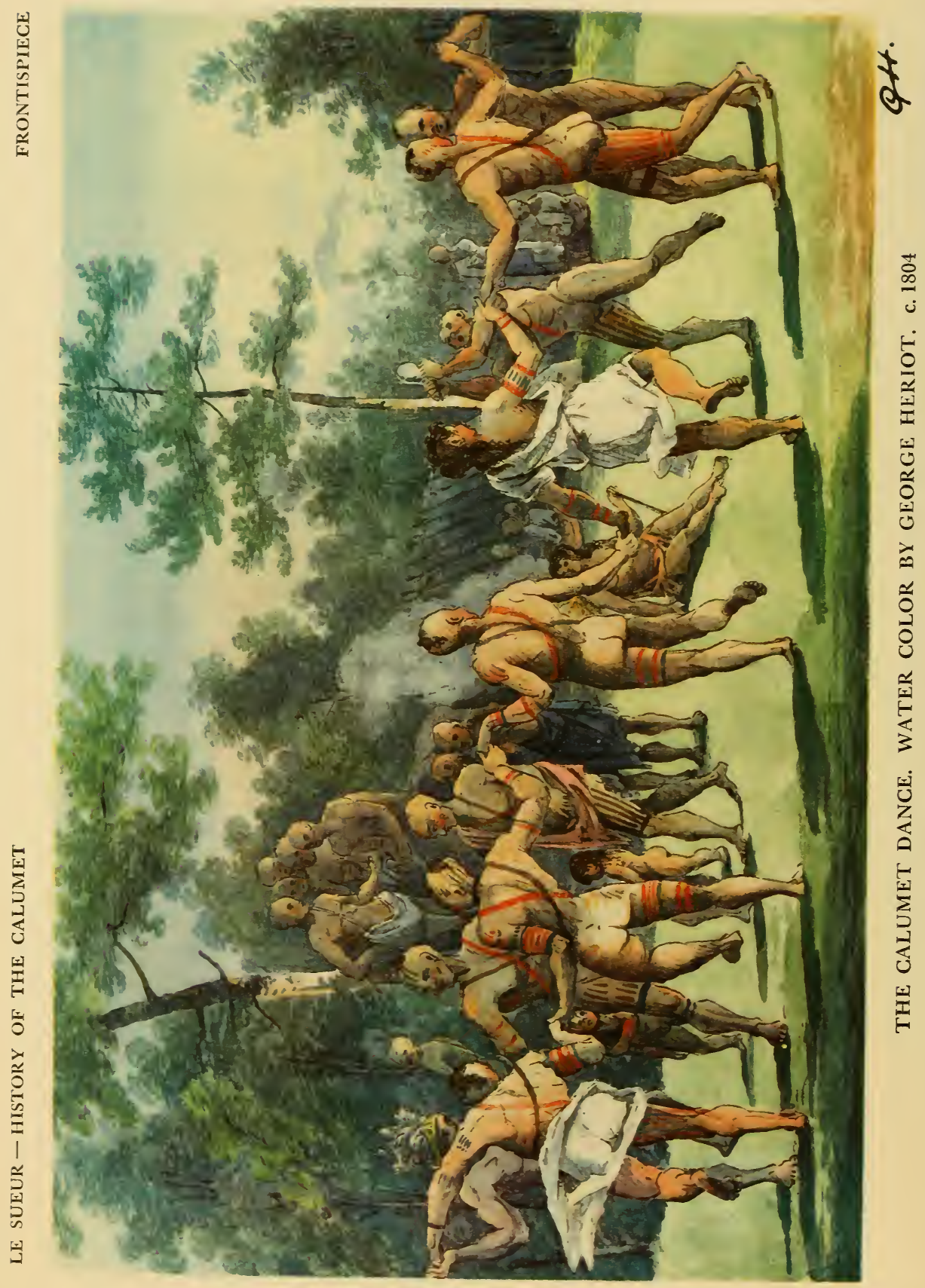


CONTRIBUTIONS FROM THE

MUSEUM OF THE AMERICAN INDIAN

HEYE FOUNDATION

Vol. XII, No. 5

\title{
HISTORY OF THE CALUMET AND OF THE DANCE
}

\author{
B Y \\ JAGQUES LE SUEUR, S.J.
}

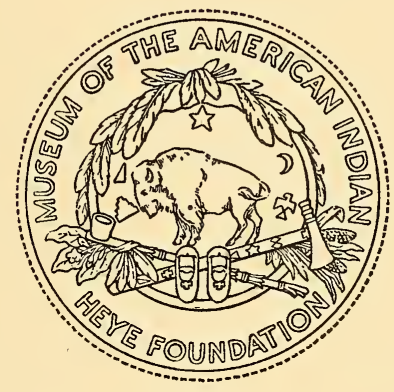

NEW YORK

MUSEUM OF THE AMERICAN INDIAN HEYE FOUNDATION

1952 


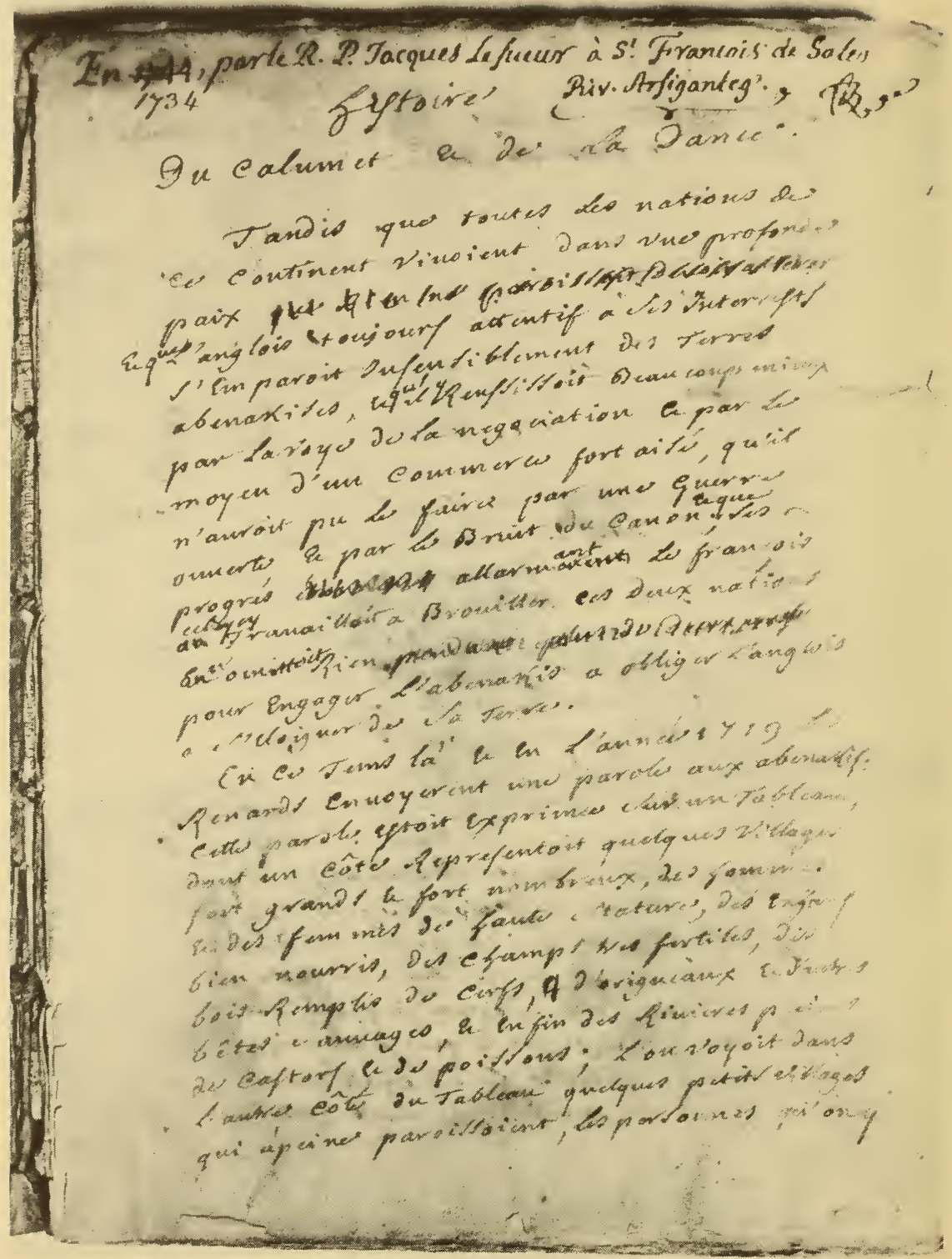

PAGE 1 OF LE SUEUR MS. 


\section{INTRODUCTION}

HE MANUSCRIPT of Jacques le Sueur, S.J., here recorded occupies twenty-one pages of a note book

used subsequently by Claude Joseph Virot, S.J., * who succeeded le Sueur at the Abnaki mission of St. François de Sales, to record, in Latin and Algonkian, instructions concerning the Mass, catechism, birth and marriage rituals and fragments of translations from the $\mathrm{New}$ Testament. In total, the volume contains 236 pages, a few of which are blank. Its cover size is $91 / 2 \times 71 / 4$ inches.

This volume was included in the Morin sale at the Anderson Galleries, New York, March 10, 1931, as Item 172. In the catalogue of that sale the dates of the various entries were stated as extending through the years 1734-1764. As will be noted in the first page of le Sueur's "Histoire", herein reproduced in reduced facsimile, the date 1744 in the heading, possibly in the hand of Virot, has been altered to read 1734; but it is believed that such correction, obviously by another pen and with different ink, is of more recent date than that of the original caption. Nor would it appear that any entry postdates 1754 .

The "Histoire du Calumet et de la Danse" was published in 1864 in Les Soirées Canadiennes, vol. IV, pp. 111-135. It appears in part, and in English translation, in Wisconsin Historical Collections, vol. XVII, pp. 191-200, 1906. It is felt, although le Sueur unfortunately describes little of the actual Calumet Dance, that his memoir deserves an unabridged recording in English particularly with the reproduction of an original water color of the dance done by George Heriot, probably in 1804 or 1805 , available to illustrate it.

* This would seem to be the Virot who left the St. Francis mission on a trip to the Ohio country in 1757 (Roubaud: Jes. Rel., vol LXX, p. 91) and who was killed by Iroquois auxiliaries near Fort Niagara in 1759. 
Heriot in his "Travels through the Canadas ... etc." has the following to say about the Calumet Dance. The quotation is from the London edition of 1807, pp. 474-476.

Having made choice of a cleared spot, they surround it with small trees and branches, cut, and placed perpendicularly in the ground, to afford a shade for those who are to compose the band. A large mat is spread, on which is placed the god of the person who gives the dance. This deity is generally a serpent, a bird, or any other thing of which he may have dreamt. On the right of the manitou are placed the calumet, with the trophies of warfare, the club, the hatchet, the bow, the quiver and arrows. The singers, consisting of both men and women, are seated under the foliage upon mats. The first part of the dance is performed by one person, who throws himself into various attitudes, and exhibits gesticulations with the calumet in his hand. In the second part he invites some warrior to join him in the dance; the latter approaches with his bow and arrows, and hatchet or club, and commences a duel against the other, who has no instrument of defense but the calumet. The one attacks, the other defends, the one aims a blow, the other parries it; the one flies, the other pursues; then he who flies wheels about, and in his turn puts his adversary to flight. All these movements are performed with set steps, and in cadence, accompanied by the sound of voices and drums, and in civilized countries might pass for the commencement of a ballet.

The dance, among the natives of America, is not considered as a simple relaxation from the more essential duties of life, or as an amusing exercise. With them it is regarded as a ceremony of religion, and practised upon occasions the most serious and solemn. Without the intervention of the dance, no public or private transaction of moment can take effect. It seems to operate as a charm, in rousing the natives from their habitual indolence and torpidity, and in inspiring them with activity and animation.

These ceremonies vary in figure, according to circumstances, or the occasions on which they are in use, and differ considerably from each other. For the calumet, for the chiefs, for war, for marriage, and for public sacrifices, distinct dances are appropriated. That of the calumet is the most striking, and appears 
to be the most serious. It is danced only on particular occurrences, when strangers pass through the country, or when the enemy sends ambassadors to offer conditions of peace. If it be by land that either the one or the other approach the village, the inhabitants depute one of their people, who advances, exclaiming that he carries the calumet of peace, whilst the strangers halt until they are invited to approach. Some of the young men then go out of the village, arrange themselves in an oval figure near the gate, and dancing whilst the strangers proceed, form a second oval, in the center of which they place the bearer of the calumet. This dance continues for half an hour, at the expiration of which the performers approach in ceremony, to receive the strangers, and to conduct them to the feast that has been prepared for the occasion. With regard to strangers who travel by water, the same formalities are observed, with this difference only, that a canoe with two or three persons in it, is despatched to the extremity of the village, bearing the calumet of peace raised like a mast in the prow.

Biographical data on Jacques Francois Eustache le Sueur are somewhat confused due no doubt, as stated in The Catholic Encyclopedia (vol. IX, p. 200), to the burning of the St. Francis mission records during Rogers' raid in 1759. He was born in France in either 1685 or 1686 . He completed his priestly studies, arrived in Canada in 1716, studied the Abnaki tongue at Sillery and was stationed as missionary at St. François de Sales. His actual years of residence there are not clearly recorded but, even after his transfer to other posts, he is said to have made repeated visits to the Abnaki well into the 1750 's.

There is also confusion as to the year of his death. One source says it occurred in Quebec in 1755, another dates it as 1760 in Montreal. As an undated memorandum (now in the collections of the State Historical Society of Wisconsin) to Reuben Gold Thwaites from Rev. A. E. Jones, S.J.. at one time archivist at St. Mary's College, Montreal, records le Sueur as being stationed at Quebec 1755-1759, it is quite 
probable that 1760 is the correct year of his death.

For the foregoing brief sketch concerning le Sueur, as well as for the short biographical data employed as foot notes to his text, we have drawn upon the Jesuit Relations (Thwaites' edition) more particularly volumes LXV and LXIX and The Catholic Encyclopedia, 1913.

The translation here used is by Mr. Richard P. Breaden and was made especially for this publication. Le Sueur's text has been re-paragraphed to make it more readable and punctuation has been altered or supplied to clarify his thought. 


\section{HISTORY OF THE CALUMET AND OF THE DANCE}

W

HILE all the nations of this continent were enjoying a deep peace the English, always alert for profit, gradually took possession of the territories of the Abenakis and succeeded much better by means of negotiations and by means of very convenient trade, than they would have been able to accomplish by open warfare and with the noise of gunfire. Their progress alarmed the French who kept working incessantly to embroil these two nations and who left nothing undone in order to compel the Abenakis to force the English to withdraw from their territories.

At this time in the year 1719 the Renards sent a message to the Abenakis. This message was expressed upon a picture, one side of which depicted some very large and very numerous villages, showed men and women tall in stature, and children who were well fed, very fertile fields, woods filled with deer and moose, and other wild animals, and finally streams filled with beaver and fish. The other side of the picture showed some small villages which were scarcely visible, and the people, which were seen there, were so thin that they could hardly stand up. There were seen there no fields producing grain, no forests filled with wild animals, and no streams which could provide beaver and fish, but only a large dragon, which was rising up halfways from the end of the picture, whose gaping jaws were threatening to swallow these wretched little villages. Here is the explanation of the picture:

My brother, you see that my country is large in extent. very fertile in the production of all kinds of grain, that my 
forests and my streams provide me in abundance with all kinds of wild animals and fish. See how well off I am, etc. I learn with sorrow that you have been reduced to a corner of an inhospitable and sterile land where you lack all the necessities of life. That is the reason for your thinness, and the death of your children whom you are not able to bring up. But that which increases immeasurably the pity which I have for you, is my seeing this great dragon with gaping jaws which is ready to devour you, and whose fury you can only avoid by prompt flight. Inasmuch as I share in all which concerns you, and that I cannot suffer you (whose flesh is dark like mine) to perish wretchedly ... I offer you my country. You will find it large enough to settle there, fertile enough to provide in abundance all your needs, and, finally, far enough away to live in security and beyond the reach of your enemies.

The Abenakis made their missionary acquainted with this message, and explained it to him naturally enough. The only respect in which sincerity was lacking, was making him realize that the English alone were represented by the dragon. This missionary, counting always on the old attachment of the Abenakis for the French nation, believed himself to have good reason to congratulate himself upon seeing that the Abenakis appeared to enter with pleasure into the plan of a reply which he suggested for them to send to the Renards. This consisted of placing the Renard and Abenaki villages upon the two sides of a picture, on top of this picture a crucifix from which shot out bright rays which cast an admirable light upon the Abenaki villages, but the Renard villages were covered with a dark cloud which cast a heavy darkness upon all their lands, and that the explanation of the picture would be this:

My brother, I am very much obliged for those sentiments of pity with which you have depicted my life of misery. It 
is true that I feel what you have represented. However, I do confess the fact that, if I am not completely unconscious of my poverty, at least I suffer it patiently, and even with joy. I have the privilege of living here with the French, who have made me know the author of my existence, Him whom I must fear and hope for after this short and miserable life. I prefer the advantages of an immortal life to all the riches and to all the pleasures which you are offering me. I can better show you my thanks only in praying that you will open your eyes to the light which the French have brought into this country.

This plan was then received apparently with applause. But the Abenakis thought more about the gifts which they had to send in exchange for those which they had received, and to appoint persons to carry them. All this was performed. But what was its success? Did the Abenakis reject the message of the Renards? Did the Renards accept the message of the Abenakis? Why waste time examining this last point? The constant hostilities, which had existed for several years between the French and the Renards, were felt enough, although these hostilities had not been mentioned in the message of the Abenakis nor even hinted at in the message which had been brought to them. But the Abenakis after having received at first the message of the Renards, did they reject it afterwards? The following facts make this judgment certain.

About two years after these messages one was on the eve of seeing two thirds of the Abenaki nation depart in order to take refuge in the country of the Renards. This took place at the beginning of the war which broke out between the Abenakis and the English. The missionary, informed about the secret plotting, gave the information promptly to the late M. de Vaudreuil, at that time governor general of this country, who fortunately was ready for the blow. It is 
not yet five years ago that the Abenakis renewed their first plan. The chief at the mission of St. François, an enemy of the French, had taken his measures so well that his plans would undoubtedly have succeeded, if God had not taken him from this world by an equally prompt and tragic death. I do not know who gave the information to the court about the alliance of the Abenakis with the Renards; I am not acquainted with the details with which this union has been described, and the exigencies which have been alleged for it. All that has come to my knowledge is the fact that the court, which does' not proceed without a knowledge of the causes, without any thought for the old attachment of the Abenakis to the French nation, nor considering the expense of the benefits to this barbarous nation - which amount to almost prodigality - has forbidden using them in the parties which were sent out against the Renards.

A year after the message of the Renards was brought to the Abenakis, the calumet dance appeared. For a whole year the calumet was kept concealed and the dance was scarcely spoken of. The person who had charge of the affair had reason to fear that neither the one nor the other would be well received. He knew that eighteen years before they had been brought out uselessly under Father Vincent Bigot,* who strongly opposed the reception of this calumet and this dance because he was acquainted with all of their ins and outs. Hence it was necessary to choose a favorable time. This took place when this person realized that the late M. de Vaudreuil had been informed of all the secrets. After having received a strong reprimand, he raised the mask and, in order to save face and to indicate his resentment, he caused at last the appearance of the calumet and the dance. The missionary at St. François, who had been a witness of what had taken place under Father Bigot, on seeing this

* With his brother, Jacques, co-founder of the St. Francis Mission, 1683. 
dance suddenly appear, surprised at its novelty, was heard to say to some savages that Christians could not take part in these diversions. He then inquired in detail of what they consisted, and here is what he learned about them:

1. That this dance was a true religious cult not only among the Renards, but also among almost all the upper nations; that it was called the Dance of the Spirit; that one was said to be dancing not at all with the calumet, but to be dancing in honor of the calumet; in a word the calumet was the god of this nation.

2. That the words which are used in the song of this dance are an invocation of the spirit.

3. That when in the councils this calumet is smoked, any man whose wife was pregnant must refrain from smoking this calumet inasmuch as his wife would not bring her fruit happily into the world, and it would undoubtedly perish.

4. That this dance is employed to summon the souls of those against whom they are going in war, and by these means to kill their enemies without question.

5. In order to conciliate foreign nations and enemies and to make a good peace with them.

6 . In order to obtain good weather and rain in accordance with the needs of the earth.

7. In order to have favorable winds for navigation.

8. That, finally, it was a specific to keep away every kind of evil and to obtain every kind of good.

According to the above account, the missionary may well ask if the custom of the calumet dance can be permitted as a thing of indifference to new Christians. And here is the way he expounded the question: Could recent Christians be permitted the use of a thing which under the appearances of singing and dancing is a religious exercise among idolatrous peoples from whom this song and this dance has been imported? The reasons for doubt were taken from the na- 
ture of the thing itself, from the character of these new Christians, from the circumstances, and, finally, from the following observations:

1. That this dance among idolatrous nations may be used for all the ends indicated above, is a fact which is proved by the testimony of all the French who have traveled in the above regions. All our savages used it. I do not think that any missionary doubts this. But the fact that words of the song may be an invocation of the spirit is not easy to prove by a large number of witnesses because the language of these nations must be understood perfectly in order to be able to judge. Father Chardon formerly asserted this.*

In this summer of 1734, the Abenakis asked M. the Marquis de Beauharnois for permission to use this dance. They used all their eloquence to persuade him that it was only a trifle; but, however, they did admit that they regarded this dance as a flag, a standard, a symbol. Falsely, they had believed that they had deceived M. the Governor by using a word which would escape his perception; but the reply which they received from him convinced them that he was not to be misled easily. Upon examination and attention to the meaning of the words flag, standard, symbol, enough was known about savages' love of expressing themselves in figurative terms, and their perfect understanding of every sense of the words with which they represent some image in their mind.

The Abenakis received the calumet dance from the Renards. This calumet dance procures union and peace among nations. The Abenakis wished to keep this flag of the Renards. If this consequence is just, would the following be less? The calumet dance is a religious cult among the Renards. The Abenakis wished to keep this dance as a flag. as a standard, as a symbol. Hence the Abenakis wished to

\footnotetext{
* Probably during the time he was stationed at the Green Bay Mission.
} 
appear at least on the exterior to have the god and the religion of the Renards. Therefore the missionary was not at all surprised when, on the return of the Abenakis from Montreal, on declaring to the chief of the present conspiracy that Christianity and this idolatrous dance could not exist together and that it was necessary to choose one or the other, he heard the savage reply coldly and firmly: Since the two things are incompatible, he would prefer to keep the calumet dance.

2. It is possible to say without calumny that the savages are scarcely men in outline. They are very rough, given up to all the corruption of the heart, and abandoned to the heaviest gloom of the spirit especially in regard to that which concerns the things of God; men consequently superstitious to excess; men attached beyond all report to their ancient customs and to the old traditions of their fathers. The missionary, persuaded that the seed of God's word could not germinate nor grow in hearts so disposed, believed in accordance with the command which God once gave his prophet that it would be necessary to pull up, destroy, scatter and to ruin before building and planting. $\mathrm{He}$ imitated the wise conduct of the industrious workman eager for an abundant harvest. We do not see this laborer planting indifferently his grain in the midst of these thick forests which surround us, he did not entrust it even in these works more exposed apparently to the benign influences of the sun. When he saw them filled with thorns and thickets, he began by cutting down, tearing up, destroying and scattering everything which could oppose his harvest. And finally he sowed.

Jesus Christ, who used the parable of the grain of seed which fell in different places, did not pretend to give lessons to workmen. In His day they were well instructed in the way to cultivate the earth, but this man of God used a 
thing very well known in order to teach men the dispositions with which they should receive the word of God in order that it might bear fruit. The missionary who groans at the little progress which religion has made in the Abenaki nation after about sixty years, who has always noticed in this nation its same mania for all its old practices, asks if he can permit in conscience this new thing, and which is certainly an idolatrous cult among nations who do not know the true God.

The great obstacles to the establishment of religion are the relations, the allegiance, the connections which those who have embraced the religion always wish to keep with their idolatries. It is suffered. It is tolerated. However, the expressed, and often repeated, prohibition cannot be ignored; that which God made formerly to his people to have no communication and to make no alliance with neighboring nations who were idolatrous, inasmuch as their example would undoubtedly lead them, themselves, into idolatry. In vain persons of an easy and accommodating disposition will reply that we are not Jews and that the law of Moses has been destroyed by the law of grace. This answer can only satisfy those who do not know what is what. There is no Catholic, no matter how slight his instruction, who does not know that God's direction over the laws of Moses, made to regulate ceremonies, stopped with the death of the Son of God, because these ceremonies were then only the shadows and the figure of that sacrifice which consummated the work of our salvation.

And the laws which protected the judicial decisions stopped also, inasmuch as the rigor of this first Testament could not accord with renewed grace. But the laws, which regulated only morals have not been abolished at all. They are obligatory no less under the law of grace than under the law of Moses, because God is always good, and evil al- 
ways bad. God in order to keep from idolatry a people which up to that time had hardly been subjected to it, prohibited them from all relations with neighboring idolatrous nations. A missionary forbids his neophytes from taking on new customs which are idolatrous among idolatrous nations. Where is the evil? The Catholic Church holds in honor everything which Judaism experiences, but this same church carefully prohibits her children from reading the books of heretics, from taking part in their meetings, and from mixing with them because she forsees that in these ways they would soon lose their faith.

Was not this wise precaution of the church based upon the law of Moses? What would one think of a man among us who would have frequent meetings with heretics, who would be present often at their preaching, and who would eat with them from time to time? Those men of an easy and accommodating disposition, would they judge him a good enough Catholic to receive the sacraments on the words which he would give them that he scarcely saw any evil in what he did, and that he acted only for his pleasure and out of pure curiosity? But what would one think of a man who after having forsworn Calvinism would continue to do what has just been said about a Catholic. The application is easy to make.

3. The fickleness and the inconstancy of savages: their education, which makes them enemies of work and of all kinds of restraint and detention; their love of independence and liberty; their dissolution in youth; their infidelity in marriage; their intemperance and their excess in drinkthese faults are only human vices. The Gospel has infallible remedies for correcting them as it has effectively corrected them in all the other nations of the world. But here is a sin of a particular nature which is peculiar to all these 
savages. It has caused even this Gospel to sift through the sieve of councils.

They are accustomed to hold councils for the slightest things in order to discuss them. They do the same thing in respect to the word of God when spoken to them; and if they hear the missionary speak about a particular virtue, of which he points out the necessity, a savage will say shortly afterwards in his cabin or in an assembly that what was heard in church was in truth very good, but surely God does not demand. it of savages. If they hear him declaim strongly against certain vices, somebody will soon provide the corrective and say: "Oh! Surely God will not demand from us an account of that, and He will not judge us by the above. Surely God will not damn a savage for such a thing."

The decision is proclaimed. An old man does the talking. The judgment is final and without appeal. The missionary has thundered in vain in his church, and vored that he is proclaiming the word of God in all its purity. The antipreachers, like those venerable magistrates of our courts who are insensible to the insults of the persons whose cases have just been lost, allow the missionary to shout but do not yield at all from the opinions they have uttered. What sentiments of pity and indignation would not be aroused in the heart of a reasonable man by the sight of one of our dogistes who, after having begged his bread all day long from door to door and being satisfied with the crumbs from a little child, suddenly sets himself up as doctor and decides the most difficult cases? The poor missionary is often a witness of this. He has to combat not only the discourses which they utter against the word of God, but also to cry out against the depravation of their morals.

Last year there was held in this mission a celebrated council, the aim of which was to escape entirely from the missionary. It was proposed that there should be selected 
two or three savages, known as prudent men, who would be instituted by the chiefs for the purpose of seeing that good order was kept in this mission. When they were invested in their position, they could not be removed. They would judge independently of the missionary what should be permitted or forbidden. Fortunately a chief upon whose religion I believe one could depend, perceiving that such a creation of office could have evil consequences, informed the missionary. The plan was attacked and broken by a union of four chiefs. It was not difficult to make them understand that if they consented to the creation of these new offices, they would have but the names of chiefs, and all their authority would be destroyed.

This year our chiefs have been scattered in different regions. Two departed to carry messages to the Aniers [Mohawks], another to the Milisakis [Malecites]. During their absence our young men supported by their partisans have won over the young chief who stayed behind. They deceived him both by their fine words and by the flattering hope that he would be like unto a sole chief in this mission through the complete devotion the youth would have for him. The temptation was too strong for a savage's ability to resist.

The missionary could assert truthfully that of all those who were the most in favor of this dance, some were very corrupt in their morals, others had no religion at all, and none of them was attached to the French. Although this dance might not have any more disadvantages than all of the rest of the dances, could it be tolerated under these circumstances?

But the Abenakis should have given up all their superstitions sixty years ago at the time they embraced Christianity. Oh! Please God that each year would not give us proofs which are only too convincing of the contrary. 
A savage came here this spring. He carried a letter from some Orange [Albany?] savages. Fearing that he would not be granted what he asked, he said that those, in behalf of whom he came, threatened to send a medicine upon the village of St. François. There would be seen there shortly a large number of dead, if they did not listen. I do not believe that there was a single person who was not frightened by the threat; and I do know, indeed, although what was asked was granted, that several retired into the forest under different pretexts and that others caused certain kinsmen to leave their cabins, although they would have received them willingly enough only a few days before. In short, all believed that the medicine of these idolatrous Oranges would undoubtedly cause some great disaster.

The missionary only asks that grace be given to the work of destroying the ancient superstitions peculiar to this nation, and that they might not be compelled to receive new superstitions - especially at a time when it is sorrowfully learned here that only two things are seen any more among our savages who are under the English; drunkenness and all kinds of trickery [de jonglerie]. The missionary of Naurantsoak [i.e., Narantsouat: Norridgewock] reports that two savages, whom he names, are causing more evil in the district there than ten zealous missionaries do good.

4. I shall not take advantage at all of the testimony of the gentlemen from the Seminary of St. Sulspice, who have charge of the mission of the Lake of Two Mountains, nor that of our fathers who reside at Sault. Their opinions and others agree perfectly with this chapter. They attribute no other reason for the decadence of Christianity in their missions. These witnesses, however, could make an impression. But here is something similar but much stronger.

If the use of the calumet dance were granted our savages under the pretext that there would be no danger of idolatry, 
I maintain that by the same token there might be introduced into this mission not only all the superstitions of idolatrous peoples, but also all those which have just been stamped out. Here is the very natural proof of this. Our savages have perfect knowledge of all the things for which idolatrous nations use the calumet dance. They know that it is the god of these peoples. However, if this dance were permitted because they assert that they intend no evil by it, and that they would use it only for their entertainment, they could use the same argument in order to revive feasts of all kinds and all the other superstitions. It would be useless and it would take too long to tell about them in detail. "We declare," they would say, "that all these actions are idolatrous among peoples who do not know God at all, but there is no danger for us who are Christians; for, in short, all these things are no more idolatrous in themselves than the calumet dance. If that were permitted us, why forbid us the others?" What is the answer? For myself I declare that I do not see it at all. However, a mission is broken by superstitions and by idolatry.

I know that the spirit of most of the people is in revolt. They cannot conceive that games, dances and feasts can be idolatrous actions. They take the liberty of blaming the conduct of the missionary. But the spirit of the missionary revolts no less at the sight of their recklessness and their ignorance. These persons should know that the first idolatry of the Jews, when they made a god, the golden calf, consisted of feasts, songs and dances. The people sat down to eat and drink, and then got up to amuse themselves. St. Paul in his first epistle to the Corinthians explains these words in this fashion: Neque idolatrae efficiamini sicut quidam ex ipsis quem ad modum scriptum est: sedit populus manducare et bibere et surrexerunt ludere. But I hear somebody mutter that I garble the passage from the thirty-second chapter 
Exodus, and that I suppress the words which precede. But here they are: Surgentesque mane obtulerunt holocausta et hostias pacificas. It is, they say, in these preceding words and not in the following that the idolatry consists.

I declare that I do not consider myself reproached. I do not believe that it would ever be advisable to reproach St. Paul, for he has garbled it as I have, or rather I cite it from his example as a thing in which idolatry does exist. It is very much more obvious in the sacrifices which the idolaters of this country offer to their spirits. These spirits are not visible at all, as the golden calf was visible. The Israelites wished to worship the golden calf. What did they do then? They killed animals, they had them cooked, they offered them before the new god who was visible. In order to consummate the sacrifice they ate the meat which they had offered. Then they sang and danced after the example of the Egyptians among whom they had seen this idolatrous cult performed. Our savages wishing to obtain some favor from their spirit kill wild animals, have them cooked, offer them in spirit to spirits which are only seen in spirit. This offering is not seen at all. They consummate the sacrifice by eating the meat, by singing and dancing; but the cooking of the meat, the offering of it, the eating of it, and the dancing and singing, all become the action itself which constitutes the sacrifice.

If there were among the Christians any fomenters of the calumet dance, they could only fall back upon the protest that the savages intend no evil in what they are doing. The following facts help over-rule this last assertion:

First fact: A person who was brought to this dance about fifteen years ago understood that in accepting this dance he was protected against all the horrible consequences of war, and that in rejecting this dance he would be undoubtedly destroyed by the enemy. In all the attempts which have 
been made since that time to establish this dance at the mission, these words have been heard spoken a hundred times by the supporters of this dance: "We are dead; they have killed us; they have taken from us the only means which we have of preserving ourselves." These words have been heard by the missionary. They were spoken after Mass by an old man in the center of the village.

Second fact: An Abenaki, outstanding in his nation by his exploits and who is the principal instigator of this dance, despairing of establishing it at St. François on its merits, withdrew in spite toward la Baye [Green Bay] in the upper country. He fell sick. Realizing that his end had come, he had Father Chardon summoned. He made his confession. He was not a saint. But nothing disturbed him more in the state in which he found himself than all he had done to have this dance accepted at St. François. He declared he knew all of its evil, and begged his confessor to tell the missionary at St. François of the sorrow with which he repented of the evil he had caused at his mission and that he would make reparation for it as best he can at death.

Third fact: At this mission one has heard the young people who were attracted toward this dance say to those persons who advised them not to: "Why do you want to stop us from doing what we are doing? It is as if we were making a mission to the Blessed Sacrament."

Fourth fact: Two years ago the calumet feathers were again brought here. They were distributed secretly in all the cabins of this mission. As for the recipients, persons from each cabin were chosen who were dependable. A recently baptized Orange woman was approached. In vain they told her that these feathers had been accepted in all the cabins, that she would undoubtedly die if she would not accept this feather. She persisted in saying that in being baptized she had renounced all the superstitions of savages. 
This good woman had not yet reached decrepit age (she was probably around forty-five years old) when she gave her missionary this information. It was well known, she told him, that her cabin was the only cabin at the mission where idolatry was not permitted at all.

Fifth fact: The chief of whom I have spoken, who perished miserably three or four years ago before going hunting for the last time, placed in the hands of his niece the feathers from the calumet entreating her to take good care of them in her box as the unique safeguard of the village and an infallible means of preserving it. The niece obeyed her uncle. Somewhat later she fell ill. Realizing that she was about to die, she summoned her missionary and told him the fault she had committed in taking care of such abominable a thing, which was regarded as the protecting deity of the village.

The calumet dance is such as has just been described. The Christians who have accepted it are such as have been depicted. Circumstances are only lacking about other rather detailed facts to see the whole enormity of it. The consequences are inevitable. In short the Abenakis use this dance in the same ways, with the same concepts for which it had been instituted, and no less than it has been used among idolatrous nations. Can it be authorized, permitted or tolerated? 



SMITHSONLAN INSTITUTION LIBRARIES

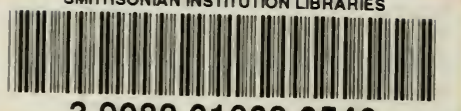

39088016090540 